\title{
Development of in vitro culture establishment conditions and micropropagation of grapevine rootstock cultivar 'Ruggeri-140'
}

\author{
Gayane Melyan ${ }^{1,2, *}$, Andranik Barsegyan ${ }^{1}$, Narek Sahakyan ${ }^{1}$, Kima Dangyan ${ }^{1}$ and Yuri \\ Martirosyan ${ }^{3,4}$ \\ ${ }^{1}$ Scientific Center of Agrobiotechnology, branch of Armenian National Agrarian University, 1101, \\ Etchmiadzin, Isi-Le-Mulino 1, Armenia \\ ${ }^{2}$ Institute of Molecular Biology of National Academy of Sciences, Hasratyan7, 0014Yerevan, \\ Armenia \\ ${ }^{3}$ All-Russia Research Institute of Agricultural Biotechnology of RAS, Timiryazevskaya St, 42 \\ Moscow, 117550, Russia \\ ${ }^{4}$ N.M. Emanuel Institute of Biochemical Physics, RAS,Kosygina Str.4, Moscow,119334 Russia
}

\begin{abstract}
Optimization of in vitro culture conditions of grapevine phylloxera-resistant rootstock cultivar 'Ruggeri-140'(Vitisberlandieri $\mathrm{x}$ Vitisrupestris) was carried out. Among the different sterilization treatments, maximum aseptic cultures were obtained for both explants apical tips and nodal segments when treated with $\mathrm{Ca}(\mathrm{ClO}) 2$ at concentration of $1.5 \%$ for 10 minutes plus $70 \%$ ethanol for $30 \mathrm{~s}$ (T7). The maximum shoot proliferation was observed both in apical and nodal meristems cultured on MS medium supplemented with $1.0 \mathrm{mg} / 1 \mathrm{BAP}$. $\mathrm{MS} / 2$ medium containing $1.0 \mathrm{mg} / 1$ indole-3-butric acid (IBA) gave the highest rooting percentage $(100 \%)$ with the highest mean number and length of roots. The ex vitro survival of rooted micro shoots was $75.0 \%$.
\end{abstract}

\section{Introduction}

Grapevine is one of the important crops grown in Armenia. Use of hardwood cuttings is the general way to propagate grapes. Basically the viruses which are causing the diseases on grapes are transmitted by this type of propagation. The use of healthy planting material is a main factor in the prevention of disease development. Thus, tissue culture is recommended to assist as well as overcome the shortcomings of the conventional method through provision of clean planting material.

The culture of meristem is the only way to obtain virus free biological material [7]. Plant pathogens, such as fungi, bacteria, viruses, viroids and nematodes can be transmitted from diseased to healthy plants. The shoot apical meristems are mainly virus free.

Since not all cells in a shoot apical meristem are infected with pathogens, it is possible to dissect out a non-infected section and manipulate this explant in vitro to produce virus-free plants $[5,11]$.

\footnotetext{
*Correspondingauthor:gmggmg65@mail.ru
} 
The process of clonal propagation can be divided into the following stages: Stage1initiation of aseptic cultures-surface sterilization. Stage II-proliferation of explants. Stage III- rooting of in vitro formed shoots. Stage IV- transfer of plantlets from in vitro to in vivo/ hardening.

The objective of this study was to optimize in vitro culture establishment and micropropagation conditions of grapevine rootstock cultivar 'Ruggeri-140'.

\section{Material and method}

The experiments were carried out at the Scientific Center of Agrobiotechnology of the Armenian National Agrarian University in 2018-2020. The cultures were established from actively growing young shoots of field grown plants. Disinfection of plant explant is the most important stage of in vitro culture procedure. Firstly leaves were removed from shoots then washed under running water for $15 \mathrm{~min}$ to remove loose dirt. After washing, the 10-15 $\mathrm{cm}$ shoots were surface disinfected with calcium hypochlorite $\mathrm{Ca}(\mathrm{OCl}) 2$ solution $(1.5 \%)$ and ethanol $(70 \%)$ with different combinations and expositions. Treated shoots were washed 4-5 times with sterile distilled water. The nodal segments and shoot tips of grapevine plants were used as explants for culture initiation. Disinfected explants were cultured on MS (Murashige and Skoog) medium containing $20.0 \mathrm{~g} / 1$ sucrose, $5.5 \mathrm{~g} / 1$ agar and different concentrations of (BAP) benzilaminopurin $(0.0,0.5,0.8,1.0$ and $1.5 \mathrm{mg} / \mathrm{l})$ and (Kin) kinetin $(0.0,0.5,0.8,1.0$ and $1.5 \mathrm{mg} / \mathrm{l})$. The cultures were incubated for 16 hours daily light of florescence white tubes with light intensities of $200 \mu \mathrm{ml} / \mathrm{m} 2 \times \sec$ at $24 \pm 2{ }^{\circ} \mathrm{C}$ temperature.

Induction of rooting: For root induction, excised microshoots (1-2 cm length) were transferred to the half-strength MS basal medium (1/2 MS) supplemented with different concentrations of Indole acetic acid (IAA) and Indole-3-butyric acid (IBA) to investigate those effects on root system formation. The cultures were kept at $25 \pm 2{ }^{\circ} \mathrm{C}$ under $16 \mathrm{~h}$ photoperiod with cool, white fluorescent lamps.

Acclimatization: Rooted plantlets were thoroughly washed to remove the agar and planted in pots containing soil, sand and peat moss $(1: 1: 1)$. The potted plants were then covered with polyethylene bags and kept under humidity $75 \%$ with the temperature of 26 $\pm 2^{\circ} \mathrm{C}$ for acclimatization for a period of 2 weeks.

Statistical Analysis: Correspondingly, data were pooled from three independent experiments and expressed as the mean. Treatment means were compared with the standard error (SE) of the mean, the student's t-test was used to find significant differences between the means.

\section{Results and Discussion}

Explants surface sterilization is the most key phase of the tissue culture procedure. It is important to eliminate the contaminants (bacteria and fungi) but without losing the biological activity of the explants.

Successful tissue culture of all plant species depends on the removal of exogenous and endogenous contaminating microorganisms [4].

Two different chemicals i.e. calcium hypochlorite and ethanol were used for the present study to standardize the best sterilization procedure for in vitro culture of phylloxeraresistant rootstock cultivar 'Ruggeri-140. The results on the effect of different concentrations of sterilants and exposure times on surface sterilization of grapevine explants are displayed in Tab 1. Explants treated with $1.5 \%$ calcium hypochlorite for 20 min (T3) showed 7.5\% contamination and 32.5\% non-growing cultures, while $1.5 \%$ 
calcium hypochlorite for $15 \mathrm{~min}$ (T4) gave $10.0 \%$ contamination and $25.0 \%$ non-growing cultures. Explants treated with 1.0\% calcium hypochlorite for $20 \mathrm{~min}$ (T1) were showed $20.0 \%$ contamination and $23.5 \%$ non-growing culture, while $1.0 \%$ calcium hypochlorite for $15 \mathrm{~min}$ (T2) was demonstrated correspondingly $32.5 \%$ and $8.5 \%$ result. Similarly the higher duration (10 $\mathrm{min}$ ) of 70\% ethanol (T5) showed lower infection (10.0\%) and maximum nongrowing cultures $(40.0 \%)$, in case of 5 minute duration (T6) infected and non-growing cultures were correspondingly $33.5 \%$ and $26.5 \%$. Maximum survival response $76.5 \%$ was observed when explants were exposed to $1.5 \% \mathrm{Ca}(\mathrm{OCl}) 2$ for $10 \mathrm{~min}+70 \%$ ethanol for $30 \mathrm{~s}$ (T7) followed by $1.5 \% \mathrm{Ca}(\mathrm{OCl}) 2$ for $15 \mathrm{~min}+70 \%$ ethanol for $1 \mathrm{~min}(\mathrm{~T} 8)$ with $71.5 \%$ survival respectively. The minimum survival (40.0\%) was recorded with $70 \%$ ethanol with 5 min exposure time (T6).

Table 1. Effect of sterilants on surface sterilization of grapevine rootstock 'Ruggeri-140' explants.

\begin{tabular}{|c|l|c|c|c|}
\hline Treatment & \multicolumn{1}{|c|}{ Sterilants /strength/ time } & $\begin{array}{c}\text { Infected } \\
\text { cultures, } \\
\text { Avg No }\end{array}$ & $\begin{array}{c}\text { Healthy } \\
\text { cultures, Avg } \\
\text { No }\end{array}$ & $\begin{array}{c}\text { Non-growing } \\
\text { cultures, } \\
\text { Avg No }\end{array}$ \\
\hline $\mathrm{T} 1$ & $1.0 \% \mathrm{Ca}(\mathrm{OCl}) 2$ for $20 \mathrm{~min}$ & $4.0 \pm 0.5$ & $11.3 \pm 0.6$ & $4.7 \pm 0.8$ \\
\hline $\mathrm{T} 2$ & $1.0 \% \mathrm{Ca}(\mathrm{OCl}) 2$ for15min & $6.5 \pm 0.6$ & $11.8 \pm 0.5$ & $1.7 \pm 0.6$ \\
\hline $\mathrm{T} 3$ & $1.5 \% \mathrm{Ca}(\mathrm{OCl}) 2$ for 20min & $1.5 \pm 0.4$ & $12.0 \pm 0.6$ & $6.5 \pm 0.5$ \\
\hline $\mathrm{T} 4$ & $1.5 \% \mathrm{Ca}(\mathrm{OCl}) 2$ for15min & $2.0 \pm 0.3$ & $13.0 \pm 0.6$ & $5.0 \pm 0.8$ \\
\hline $\mathrm{T} 5$ & $70 \%$ ethanol for $10 \mathrm{~min}$ & $2.0 \pm 0.5$ & $10.0 \pm 0.6$ & $8.0 \pm 1.0$ \\
\hline $\mathrm{T} 6$ & $70 \%$ ethanol for $5 \mathrm{~min}$ & $6.7 \pm 0.4$ & $8.0 \pm 0,5$ & $5.3 \pm 0.6$ \\
\hline $\mathrm{T} 7$ & $\begin{array}{l}1.5 \% \mathrm{Ca}(\mathrm{OCl}) 2 \text { for 10min } \\
+70 \% \text { ethanol for 30s }\end{array}$ & $1.3 \pm 0.4$ & $15.3 \pm 0.6$ & $3.4 \pm 0.5$ \\
\hline $\mathrm{T} 8$ & $\begin{array}{l}1.5 \% \mathrm{Ca}(\mathrm{OCl}) 2 \text { for 15min } \\
+70 \% \text { ethanol for } 1 \mathrm{~min}\end{array}$ & $1.1 \pm 0.1$ & $14.3 \pm 1.0$ & $4.6 \pm 05$ \\
\hline
\end{tabular}

Note. 20 explants were used per treatment and each treatment was repeated thrice.

Meristem proliferation and multiplication was initiated from apical and nodal explants of grapevine rootstock cultivar 'Ruggeri-140' within 7-10 days of inoculation onto MS basal medium supplemented with BAP and Kin. Twenty explants were used for each treatment and every treatment was repeated three times. There was no sign of shoot proliferation when explants were cultured in media without of cytokinins.

The stimulatory effect of cytokinins on the in vitro proliferation and development of shoots from shoot tips and nodal-buds of grapevine species is well known [6, 10].

There were differences among the treatments for the mean number of shoots/culture. The apical and nodal shoots proliferated and elongated to $1.5-2.5 \mathrm{~cm}$ within four weeks of culture. Among the various concentrations of cytokinin tested, $1.0 \mathrm{mg} / 1 \mathrm{BAP}$ was more effective for inducing shoots within a month from apical and nodal meristems (Tab 2).

The superiority of BAP over Kin for shoot initiation has also been reported in Cyclea peltata [3] and Morinda citrifolia [9] etc. There were differences among the treatments for mean number of shoots/explant. The nodal meristems produced more number of shoots (2.97) than the apical meristems (2.31). At higher concentrations (1.5mg/l) of BAP and Kin, the rate of shoot proliferation declined. On the contrary, Abido et al [1] found highest mean number of shoots at $2.0 \mathrm{mg} / \mathrm{l}$ of BAP. The frequency of shoots per culture varied from 1.00 to 2.97 . 
Table 2. Effect of BAP, Kin on shoot from apical (A) and nodal (B) meristems of grapevine after 4 weeks of culture.

\begin{tabular}{|c|c|c|c|}
\hline \multicolumn{2}{|c|}{ MS + Growth regulators, (mg/l) } & Number of shoots/explant, (Mean \pm S.E.) \\
\hline $\mathrm{BA}(\mathrm{mg} / \mathrm{l})$ & $\operatorname{Kin}(\mathrm{mg} / \mathrm{l})$ & $\mathrm{A}$ & $\mathrm{B}$ \\
\hline 0 & 0 & - & - \\
\hline 0.5 & 0 & $1.41 \pm 0.3$ & $1.74 \pm 0.3$ \\
\hline 0.8 & 0 & $1.70 \pm 0.3$ & $2.25 \pm 0.2$ \\
\hline 1.0 & 0 & $2.31 \pm 0.2$ & $2.97 \pm 0.3$ \\
\hline 1.5 & 0 & $1.00 \pm 0.1^{*}$ & $1.30 \pm 0.2^{*}$ \\
\hline 0 & 0.5 & $1.17 \pm 0.2$ & $1.36 \pm 0.3$ \\
\hline 0 & 0.8 & $1.30 \pm 0.3$ & $1.50 \pm 0.2$ \\
\hline 0 & 1.0 & $1.80 \pm 0.2$ & $2.12 \pm 0.2$ \\
\hline 0 & 1.5 & $1.00 \pm 0.2^{*}$ & $1.20 \pm 0.1^{*}$ \\
\hline
\end{tabular}

Note. $*$ (with callus)

The in vitro raised shootlets were subcultured on $1 / 2$ strength MS medium supplemented with auxins (IAA, IBA- $0.5 \mathrm{mg} / 1$ to $2.0 \mathrm{mg} / \mathrm{l}$ ) for grapevine rootstock 'Ruggeri-140' root formation. The results of our study showed that roots were unable to root on MS/2 nutrient medium free of auxins.

Table 3. Effect of different concentrations and combinations of IBA and IAA on root formation.

\begin{tabular}{|c|c|c|c|}
\hline Conc. of IBA, (mg/l) & Conc. of IAA, (mg/l) & $\begin{array}{c}\text { Number of roots } \\
\text { Mean } \pm \text { SD }\end{array}$ & Response (\%) \\
\hline Control (0.0) & - & $0.00 \pm 0.0$ & 0 \\
\hline 0.5 & - & $3.02 \pm 0.5$ & 86 \\
\hline 1.0 & - & $5.34 \pm 0.4$ & 100 \\
\hline 1.5 & - & $1.53 \pm 0.2^{*}$ & 67 \\
\hline 2.0 & - & $1.00 \pm 0.3^{*}$ & 71 \\
\hline- & 0.5 & $2.24 \pm 0.2$ & 75 \\
\hline- & 1.0 & $3.66 \pm 0.6$ & 90 \\
\hline- & 1.5 & $1.87 \pm 0.5^{*}$ & 85 \\
\hline- & 2.0 & $1.10 \pm 0.2$ & 70 \\
\hline
\end{tabular}

Note $*$ (with callus)

For in vitro rooting, half-strength MS medium supplemented with $1.0 \mathrm{mg} / \mathrm{l}$ of IBA was most effective, which was consistent with the in vitro rooting studies of other woody plants $[2,8]$.

The in vitro root system with callus showed less qualitative; because the cuttings with such root system developed significantly less roots per rooted cuttings than cuttings without callus at both auxin treatments. In vitro rooted plantlets were successfully acclimatized, with $75.0 \%$ survival rate.

\section{Conclusions}

The results obtained in the present work demonstrate efficient in vitro plant regeneration and multiplication of grapevine rootstock 'Ruggeri-140'. In summary, (i) explants of rootstock 'Ruggeri-140' can be successfully surface sterilized using combination of $1.5 \%$ $\mathrm{Ca}(\mathrm{OCl}) 2$ for $10 \mathrm{~min}+70 \%$ ethanol for $30 \mathrm{~s}$, (ii) the best shoot proliferation was obtained on MS medium supplemented with $1.0 \mathrm{mg} / \mathrm{l} \mathrm{BAP,} \mathrm{(iii)} \mathrm{the} \mathrm{best} \mathrm{root} \mathrm{induction} \mathrm{was} \mathrm{obtained}$ on half-strength MS basal medium supplemented with $1.0 \mathrm{mg} / \mathrm{l} \mathrm{IBA}$, rooted plantlets were successfully acclimatized, with $75 \%$ survival rate in plastic pots containing soil, sand and 
peat moss $(1: 1: 1)$. It was found out that the productivity of plant regeneration and root formation depends on the used phytohormones and their concentrations. This protocol would serve for mass multiplication and crop improvement programmes.

\section{Acknowledgments}

We gratefully acknowledge the financial support from the State Committee of Science of Armenia for the conducted research in the scope of the 18T-4D083 project.

\section{References}

1. A.I.A. Abido, M.A.M. Aly, Sabah A. Hassanen and G.A. Rayan, Middle-East J. of Scient. Res. 13 (3), 328-337 (2013) https://idosi.org/mejsr/mejsr13(3)13/8.pdf

2. N. M. Aikaterini, M. Papafotiou, Hortscience 55(4), 436-443 (2020)_https://doi.org/1 0.21273/HORTSCI14584-19

3. J. Abraham, M. K. Cheruvathur, B. Mani, T. D. Thomas J.Indust. Crops and Prod. 31(1), 92-98 (2010) doi: 10.1016/j. indcrop.2009.09.011

4. P.M. Buckley and B.M. Reed, Antibiotic susceptibility of plant-associated bacteria. Hort Science, 29(5), 434(1994) https://doi.org/10.21273/HORTSCI.29.5.434c

5. Grout B.W.W., In: Hall R.D. (eds) Plant Cell Cult. Protocols. Methods In Mol. Biol. ${ }^{\mathrm{TM}}$, vol 111. (1999) https://doi.org/10.1385/1-59259-583-9:115

6. K. Seung-Heui and K. Seon-Kyu, J. of Plant Biotech., 29 (2), 123-127 (2002) https://doi.org/10.5010/JPB.2002.29.2.123

7. G. Loebenstein, P. H. Berger, A. A. Brunt, and R. H. Lawson, Book Virus and viruslikediseases of potatoes and production of seed potatoes, XV, 460, 195-225 (2001) https://doi.org/10.1007/978-94-007-0842-6

8. H.S. Nuroniah and R. Bogidarmanti, IOP Conf. Ser.: Earth Environ. Sci. (533) 012030, (2020) https://iopscience.iop.org/article/10.1088/1755-1315/533/1/012030

9. S.M. Shekhawat, N. Kannan, M. Manokari, C.P. Ravindran, J.of Appl Res.on Medic. And Arom.plants, 2(4), 174-181 (2015) DOI 10.1016/j.jarmap.2015.06.002

10. L. Torregrosa, A. Bouquet, P.G Goussard, In: Roubelakis-Angelakis K.A. (eds) Mol. Biolog \&Biotech.on Grapevine. Springer, Dordrecht. 281-326 (2001) https://doi.org/10.1007/978-94-017-2308-4_12

11. J. Patzak, A. Henychová, P. Svoboda, I. Malířová, Czech Journal of Genetics and Plant Breeding, 56, 159-164 (2020) https://doi.org/10.17221/27/2020-CJGPB 